\title{
Effect of daily versus intermittent iron therapy in pregnant women: hematological and pregnancy outcome
}

\author{
Kumar Agrawal S. ${ }^{1}$, Jindal M. ${ }^{2 *}$ \\ DOI: https://doi.org/10.17511/joog.2020.i03.01
}

1 Shrikrishna Kumar Agrawal, Assistant Professor, Department of Obstetrics and Gynaecology, Shri Shankaracharya Institute of Medical Sciences, Bhilai, Chhattisgarh, India.

2* Monika Jindal, Associate Professor, Department of Obstetrics and Gynaecology, Shri Shankaracharya Institute of Medical Sciences, Bhilai, Chhattisgarh, India.

Background: The purpose of this study was to compare daily iron supplementation and intermittent iron supplementation in preventing anemia in healthy pregnant women. Material and Method: Prospective Randomized Clinical Trial. From May 2004 - December 2006, 141 healthy pregnant women without anemia, between 14 - 20 weeks of pregnancy were randomly allocated into two equal groups. Completed data were obtained in 110 patients, 55 in each group. The first group ( $\mathrm{n}=$ 55) received a $100 \mathrm{mg}$-ferrous sulfate tablet daily, the second group $(\mathrm{n}=55)$ received a $100 \mathrm{mg}-$ ferrous sulfate tablet two tablets once weekly, respectively till delivery. Serum hemoglobin, ferritin, and iron were measured before and after the supplementation. Paired $t$ and ANOVA tests were used as appropriate. Results: There were no significant differences between the pre- and post-treatment hemoglobin levels $(p=0.871)$ and serum ferritin levels $(p=0.741)$ with iron supplementation in the two groups when the maternal hemoglobin level was $>11 \mathrm{~g} / \mathrm{dL}$ before enrolment. However, For those women who had a hemoglobin concentration $<11 \mathrm{gm} / \mathrm{dL}$ at the beginning, the rise in hemoglobin concentration was significantly greater at the end in the daily supplemented group as compared to the weekly group $(1.44 \pm 1.51 \mathrm{gm} / \mathrm{dl}$ vs. $0.12 \pm 1.05 \mathrm{gm} / \mathrm{dl}, \mathrm{p}=0.015)$. Although when the changes in the serum ferritin level which occurred in each group were compared, there was no significant difference $(p=0.415)$ between the two intervention groups. Conclusions: These results suggest, daily or weekly iron supplementation is equally effective for healthy pregnant women without anemia.

Keywords: Iron supplementation, Pregnant women, Anaemia

\section{Corresponding Author}

Monika Jindal, Associate Professor, Department of Obstetrics and Gynaecology, Shri Shankaracharya Institute of Medical Sciences, Bhilai, Chhattisgarh, India.

Email: drmonickajindal@gmail.com
How to Cite this Article

Agrawal SK, Jindal M. Effect of daily versus intermittent iron therapy in pregnant women: hematological and pregnancy outcome. Obs Gyne Review J Obstet Gynecol. 2020;6(3):57-66. Available From https://obstetrics.medresearch.in/index.php/joog/art icle/view/102
To Browse

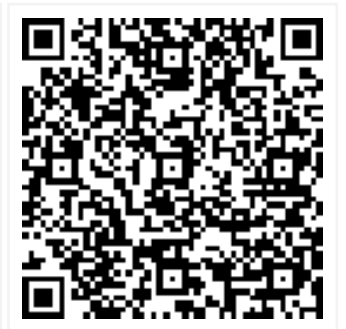

Manuscript Received 04-03-2020

Conflict of Interest No
Review Round 1 12-03-2020

Funding

Review Round 2
$17-03-2020$
Ethical Approval
Yes

Review Round 2 Yes
Review Round 3

Plagiarism X-checker $14 \%$
Accepted 23-03-2020

(c) 2020 by Shrikrishna Kumar Agrawal, Monika Jindal and Published by Siddharth Health Research and Social Welfare Society. This is an Open Access article licensed under a Creative Commons Attribution 4.0 International License https://creativecommons.org/licenses/by/4.0/ unported [CC BY 4.0]. 


\section{Background}

Iron requirements increase during pregnancy $[1,2]$. And this requirement may lead to anemia in pregnant women $[3,4]$. Lower hemoglobin cut off is $11.0 \mathrm{~g} / \mathrm{dL}$ in the first and last trimester and 10.5 $\mathrm{g} / \mathrm{dL}$ in the second trimester. Therefore, any level below $10.5 \mathrm{~g} / \mathrm{dL}$ should be considered as anemia [5]. Iron consumption for pregnant women is undesirable, because of the side effects. The probable cause is the effect of oxidative stress of high doses of Iron, which leads to gastrointestinal intolerance [3].

As gut mucosal turnover rates are about three days, administering iron during these days may lead to lower iron absorption. Periodic iron supplementation may let the mucosa to heal and gets better iron absorption [6-8]. Previous studies reported, continuous administration of oral iron impairs the absorption of a subsequent iron dose [9]. A few experimental studies demonstrated that alternative efficacious iron supplementation regimens might reduce undesirable side-effects [10].

Significant equality and reduced side effects have been reported in several epidemiological studies in comparing the weekly prescription of iron with daily supplementation [3-7]. In the other studies, there was not found a difference between daily and twiceweekly iron supplementation regimens in preventing iron deficiency anemia in children, non-pregnant women, and pregnant women in their early trimesters [12-14]. And in another study, the intermittent regimen was shown to be superior to daily regimen [3-15]. In human beings, gut mucosal turnover occurs every 3 days.

Thus, weekly rather than daily administration of iron has been proposed as a safe, beneficent, and costeffective method to prevent and alleviate anemia in pregnant women [12-17]. As mentioned above there are different study which studied the effect of iron separately in daily use and weekly and three times. Thus authors aimed to compare the effects of daily and weekly iron supplementation regimens on hematological markers in pregnant women without anemia.

\section{Methods}

Setting: Department of Obstetrics and Gynecology, PBM Medical College, Bikaner, Rajasthan, India.

Duration of study: May 2004 to December 2006
Type of study: Prospective simply randomized clinical trial

Sampling methods: Unstratified variable block size random allocation

Sample size calculation: Sample size calculation was carried out. A sample size of 54 in each group would have $90 \%$ power to detect a difference in a mean of $2 \mathrm{~g} / \mathrm{dL}$ in hemoglobin (the difference between the anticipated daily supplementation mean of $12 \mathrm{~g} / \mathrm{dL}$ and the weekly supplementation mean of $10 \mathrm{~g} / \mathrm{dL}$ ) assuming the common standard deviation of 3.5 using a two-way t-test with a 0.05 one-sided significance level. Therefore, we planned to include 55 subjects in each arm of the study. Block randomization (block size $=10$ ) was used as a method of allocating the subjects into one of two groups: one receiving daily and the other receiving weekly iron supplementation.

Inclusion criteria: All the pregnant women who attended the antenatal clinics before the 20th week of gestation were included in the study.

Exclusion criteria: Women with hemoglobin levels less than $10 \mathrm{~g} / \mathrm{dL}$, chronic hematological disorders (thalassemia, etc.), history of chronic illness e.g. liver or renal disease, recurrent urinary tract infection (UTI), tuberculosis, malaria, heart disease; the history of menorrhagia, bleeding disorders, chronic peptic ulcer, bleeding piles; women taking drugs e.g. antiepileptics, NSAIDs, antithyroid; the history of prior blood transfusion; obstetric hemorrhage is present or past pregnancies and multiple pregnancies were excluded from the study.

Data collection procedure: Hundred forty-one pregnant women without exclusion criteria were enrolled in the study between 14th to 20 weeks of gestation. Written informed consent was obtained from all the participants. The Ethics Committee of the hospital approved the study protocol. The women were divided into two equal groups. All the groups were matched in terms of age, numbers of pregnant, income, and education. Standard Govt. of India supply of Irofol (large) tablets was used throughout the study. Each tablet contains dried ferrous sulfate IP $335 \mathrm{mg}$ equivalent to $100 \mathrm{mg}$ of elemental ferrous iron and folic acid $500 \mu \mathrm{g}$.

Women in group I $(n=55)$ were instructed to take one tablet daily and supplied 3 blister packets (total of 30 tablets) for 1 month. Women in group II $(n=55)$ were supplied one blister packet (10 tablets) to cover one month. They were instructed to choose 
Any day of the week and take two tablets on that day - one before lunch and the other before dinner (total $200 \mathrm{mg}$ elemental iron/week). No tablets were given for the rest of the week and the regimen was repeated weekly. All women were instructed to take their iron tablets before their meals (30 minutes approx.) and not to take them with tea, coffee, or milk. They were advised to take calcium supplements after meals. Health education regarding the importance of diet in pregnancy, ironrich food appropriate dietary practices was given to all.

Patients were advised to bring back their blister packets at each ANC visit. The number of days for which the drugs were consumed was recorded. An attempt was made to verbally verify compliance, and by checking the used blister packets. Patients were informed about the usual side effect of iron preparations and told to report nausea, vomiting, bowel disturbances, or any other complications. They were also to report if severe intolerance caused them to stop taking supplements. Serum hemoglobin, serum ferritin, and serum iron levels were measured for all pregnant women who attended the antenatal clinics before the 20th week of gestation.

A complete hemogram was repeated at 1 month and 3 months after starting supplementation. Final hemogram and serum ferritin estimation were done at 32-34 weeks period of gestation.

All women were followed till term. They continued to take iron supplements until delivery. The total number of tablets consumed in pregnancy, the period of gestation at delivery, and birth weight were noted.

Ethical consideration: The Ethics Committee of the hospital approved the study protocol

Table-1: Reason for attrition.

\begin{tabular}{|l|l|l|l|}
\hline \multirow{2}{*}{\multicolumn{2}{c|}{ Reason }} & \multicolumn{3}{c|}{ No. of patients } \\
\cline { 2 - 5 } & Total & Daily & Weekly \\
\hline Refused further blood sampling & 2 & 1 & 1 \\
\hline Changed residence & 1 & 0 & 1 \\
\hline Miscarriage & 3 & 2 & 1 \\
\hline IUD & 2 & 2 & 0 \\
\hline APH - abruption - 1, previa - 1 & 2 & 2 & 0 \\
\hline Preterm & 2 & 0 & 0 \\
\hline Lost to follow up & 8 & 6 & 2 \\
\hline Changed iron preparation & 9 & 7 & 2 \\
\hline Therapy discontinued & 2 & 1 & 1 \\
\hline & 31 & 21 & 10 \\
\hline
\end{tabular}

Statistical analysis- Data on all subjects were entered into a computer database and analysis was performed using SPSS 18 advanced statistics program. All hematological variables fitted into normal distribution and parametric analysis using mean, standard error of mean and standard deviation were employed. The significance of the difference between the daily and weekly supplemented groups was assessed by the student's t-test for unpaired values and the chi-square test for non-parametric variables. Correlations were calculated using Pearson's coefficient of correlation.

The significance level was set at $p<0.05$. The main outcome measurements were a comparison of mean hemoglobin and ferritin levels, at the beginning and end of the supplementation period between the two treatment groups (between-subjects factor) as well as a comparison of the change within each group (within-subject factor). These treatment effects were compared by using analysis of variance (ANOVA). Kaplan-Meier analysis was performed to determine whether there was a significant difference in the probability of improvement relative to the time in the two groups.

\section{Results}

One hundred and forty-one women were initially enrolled in the study. Completed data were obtained in 110 patients - 55 in the daily supplemented group and 55 in the weekly supplemented group. The reasons for attrition are shown in Table 1. Reasons which were common to both groups included: 2 women refused a second blood collection; 1 woman changed residence and 8 women were lost to follow up. Nine women had miscarriage/delivery before 32 weeks gestation and were excluded because the final ferritin level could not be done.

More women $(n=7)$ complained of severe GI intolerance in the daily group as compared to the weekly group $(n=2)$ and changed the iron preparation. In two women iron supplementation was discontinued because of severe vomiting. Both the patients had $\mathrm{Hb}<12 \mathrm{gm} / \mathrm{dL}$ at the start of their pregnancies and received only a dietary source of iron. Repeat haemoglobin levels at 34 weeks period of gestation were > 11gm/dL $(\mathrm{n} 1=11.2 \mathrm{gm} / \mathrm{dL}$; $\mathrm{n} 2=11.3 \mathrm{gm} / \mathrm{dL})$.

At baseline, $41.8 \%$ of the women in the daily group $(n=23)$ and $25.5 \%$ of the women in the weekly group $(n=14)$ had hemoglobin concentration 
$<11 \mathrm{gm} / \mathrm{g}$ L. of the women who were in the first trimester of pregnancy, $(n=74$, Daily $=33$, Weekly $=41), 42.42 \%$ of the daily $(n=14)$ and $14.63 \%$ of the weekly $(n=6)$ group were anemic, with a hemoglobin concentration $<11 \mathrm{gm} / \mathrm{d} \mathrm{L}$. of the women in the second trimester $(n=36$, Daily $=22$, Weekly $=14), 45.45 \%$ of the daily $(n=10)$ and $57.14 \%$ of the weekly $(n=8)$ group had hemoglobin < $11 \mathrm{gm} / \mathrm{dL}$.

At baseline $69 \%$ (38 out of 55 ) and $49.1 \%$ (27 out of 55) of women supplemented daily had serum ferritin values $<20 \mathrm{ng} / \mathrm{ml}$ and $<12 \mathrm{ng} / \mathrm{ml}$, respectively. For the women supplemented weekly this prevalence was $87.2 \%$ (48 out of 55 ) and $69 \%$ (38 out of 55 ) respectively.

Both $\mathrm{Hb}$ concentration $<11 \mathrm{gm} / \mathrm{dL}$ and serum ferritin concentration $<12 \mathrm{ng} / \mathrm{ml}$ were found in $23.6 \%$ (13 out of 55 ) of the group supplemented daily and in $20 \%$ (11 out of 55 ) of the group supplemented weekly. So overall prevalence of IDA in this population was $21.81 \%$ (24 out of 110 ) whereas $60.9 \%$ (67 out of 110 ) were iron deficient and $39.09 \%$ (43 out of 110 ) of the population were iron deficient but non-anemic.

At the end of the study, the prevalence of anemia had increased in the weekly group $25.5 \%$ to $41.8 \%$ (14 out of 55). In the daily group the prevalence had decreased from $41.8 \%$ to $25.5 \%$ (14 out of 55 ).

The prevalence of iron deficiency as measured by serum ferritin concentrations $<12 \mathrm{ng} / \mathrm{ml}$ was $49.1 \%$ (27 out of 55) and $80 \%$ (44 out of 55) in women supplemented daily and weekly respectively at the end of the study.

Prevalence of IDA in the daily supplemented group had decreased from $23.6 \%$ to $12.7 \%$ whereas in the weekly group it had increased from $20 \%$ to $34.5 \%$ (Table 2).

Table 2: Prevalence of iron deficiency and anemia in the supplementation groups before and after treatment.

\begin{tabular}{|c|c|c|}
\hline & $\begin{array}{l}\text { Before Treatment } \\
\qquad(n=55)\end{array}$ & $\begin{array}{l}\text { After Treatment } \\
\qquad(\mathrm{n}=55)\end{array}$ \\
\hline \multicolumn{3}{|l|}{ Daily Group $(n=55)$} \\
\hline $\mathrm{Hb}$ con. $<11 \mathrm{gm} / \mathrm{dl}$ & $41.8 \%(n=23)$ & $25.5 \%(n=14)$ \\
\hline Se Ferritin $<12 \mathrm{ng} / \mathrm{ml}$ & $49.1 \%(n=27)$ & $49.1 \%(n=27)$ \\
\hline $\begin{array}{l}\text { Both } \mathrm{Hb}<11 \mathrm{gm} / \mathrm{dl} \text { and Se Fe } \\
<12 \mathrm{ng} / \mathrm{ml}\end{array}$ & $23.6 \%(n=13)$ & $12.7 \%(n=7)$ \\
\hline \multicolumn{3}{|l|}{ Weekly group $(n+55)$} \\
\hline $\mathrm{Hb}$ con. $<11 \mathrm{gm} / \mathrm{dl}$ & $25.5 \%(n=14)$ & $41.8 \%(n=23)$ \\
\hline
\end{tabular}

\begin{tabular}{|l|l|l|}
\hline Se Ferritin < $12 \mathrm{gm} / \mathrm{ml}$ & $69.0 \%(\mathrm{n}=38)$ & $80.0 \%(\mathrm{n}=44)$ \\
\hline Both $\mathrm{Hb}, 11 \mathrm{gm} ; \mathrm{dl}$ and Se Fe $<12 \mathrm{ng} / \mathrm{ml}$ & $20 \%(\mathrm{n}=11)$ & $34.5 \%(\mathrm{n}=19)$ \\
\hline
\end{tabular}

In the beginning, the mean hemoglobin level in the daily supplemented group was $11.32 \pm 1.04 \mathrm{gm} / \mathrm{dL}$ and in the weekly supplemented group $11.63 \pm 0.91$ $\mathrm{gm} / \mathrm{dL}(\mathrm{p}=0.164)$, Initial mean serum ferritin level in the daily group was $18.41 \pm 21.97 \mathrm{ng} / \mathrm{ml}$ and was higher than in the weekly group $(9.96 \pm 8.74 \mathrm{ng} / \mathrm{ml})$. The difference was statistically significant $(p=0.027)$.

In the daily group there was $0.37 \pm 1.48 \mathrm{gm} / \mathrm{dL}$ increase in hemoglobin $(p=0.116)$ at the end of supplementation; the comparative change in the weekly group was $-0.21 \pm 1.45 \mathrm{gm} / \mathrm{dL} \quad(p=0.316)$. Thus there was no significant increase in hemoglobin in either group.

Mean serum ferritin level increased marginally in the daily group from $18.41 \pm 21.97 \mathrm{ng} / \mathrm{ml}$ to $21.24 \pm 26.25 \mathrm{ng} / \mathrm{ml}$ (mean rise $2.83 \pm 24.98 \mathrm{ng} / \mathrm{ml}$, $9 p=0.477$ ) but the rise was not statistically significant. In the weekly group the mean serum ferritin level decreased from $9.96 \pm 8.74 \mathrm{ng} / \mathrm{ml}$ to $9.21 \pm 12.15 \mathrm{ng} / \mathrm{ml}$ (mean fall $-0.75 \pm 11.41 \mathrm{ng} / \mathrm{ml}$, $p=0.68$ ) but the failure was not statistically significant.

The final ferritin level in the weekly group was significantly lower $(p=0.01)$ than the corresponding values in the daily group. However the initial values were also significantly lower. The change in the ferritin level in the daily group was not significantly different from that in the weekly group $(p=0412)$.

Among the RBC indices, - hematocrit, MCV, and $\mathrm{MCH}$ levels were not different between the two treatment groups either at the start or at the end of supplementation. In the weekly supplemented group, there was a marginal fall in the values of $\mathrm{HCT}, \mathrm{MCV}$, and $\mathrm{MCH}$ after an average of 17 weeks of iron supplementation, but these within-group changes were not statistically significant.

On the other hand, in the daily supplemented group - there was a minimal increase in mean HCT, MCV, and $\mathrm{MCH}$ values, though not statistically significant. Initial and final MCHC levels were significantly higher in the daily group $(p<0.05)$ as compared to the weekly group.

However, the mean increase in MCHC seen either group was not significantly different $(0.51 \pm 2.34$ vs. $0.41 \pm 2.09 \mathrm{gm}$. $\mathrm{dl}, \mathrm{p}=0.221$ ) between the groups (Table 3). 
Table 3: Haematological values at the beginning and end of the supplementation period.

\begin{tabular}{|l|l|l|l|l|}
\hline \multicolumn{1}{|c|}{ Study group } & Beginning & End & Difference & $\begin{array}{c}\text { p- } \\
\text { value }\end{array}$ \\
\hline Daily group $(\mathrm{n}=55)$ & & & & \\
Hb (mg/dL) & $11.32 \pm 1.04$ & $11.70 \pm 1.13$ & $0.37 \pm 1.48$ & 0.116 \\
- HCT (\%) & $34.06 \pm 2.49$ & $34.38 \pm 3.06$ & $0.31 \pm 3.34$ & 0.558 \\
- MCV (fl) & $86.31 \pm 4.51$ & $87.35 \pm 7.04$ & $1.04 \pm 5.38$ & 0.226 \\
- MCHC (pg) & $29.15 \pm 1.79$ & $29.70 \pm 2.69$ & $0.55 \pm 2.41$ & 0.154 \\
- Se.ferritin(ng/ml) & $18.41 \pm 21.97$ & $21.24 \pm 26.25$ & $2.83 \pm 24.98$ & 0.477 \\
\hline Weekly group $(\mathrm{n}=55)$ & $33.43 \pm 2.14$ & $33.94 \pm 1.98$ & $0.51 \pm 2.34$ & 0.173 \\
- Hb (mg/dL) & $11.63 \pm 0.91$ & $11.42 \pm 1.35$ & $-0.21 \pm 1.45$ & 0.361 \\
- HCT (\%) & $34.94 \pm 2.87$ & $34.73 \pm 3.68$ & $-0.21 \pm 3.31$ & 0.691 \\
- MCV (fl) & $87.63 \pm 521$ & $86.36 \pm 7.56$ & $-1.26 \pm 6.33$ & 0.213 \\
- MCHC (pg) & $29.00 \pm 2.06$ & $28.43 \pm 2.80$ & $-0.57 \pm 2.54$ & 0.163 \\
- MCHC (gm/dL) & $32.51 \pm 1.79$ & $32.92 \pm 1.67$ & $-0.41 \pm 2.09$ & 0.221 \\
- Se. ferritin (ng/ml) & $996 \pm 8.74$ & $9.21 \pm 12.15$ & $-0.75 \pm 11.41$ & 0.680 \\
\hline
\end{tabular}

Table 4: Haematological values at baseline and follow up.

\begin{tabular}{|c|c|c|c|c|c|c|}
\hline Hemoglob & Wee & Daily & & Weekly & Difference & P- \\
\hline in & k & n $\mathrm{gm} / \mathrm{dl}$ & N & $\mathrm{gm} / \mathrm{dl}$ & $\mathrm{gm} / \mathrm{dL}$ & value \\
\hline Baseline & 0 & \begin{tabular}{|l|l|}
55 & $11.32 \pm 1.04$
\end{tabular} & 55 & $11.63 \pm 0.91$ & 0.31 & 0.164 \\
\hline 1st Visit & 4 & \begin{tabular}{l|l}
37 & $11.34 \pm 0.74$
\end{tabular} & $\mid 46$ & $14.11 \pm 16.52$ & 2.77 & 0.387 \\
\hline 2nd Visit & 12 & $51 \mid 11.38 \pm 0.88$ & 51 & $11.21 \pm 0.96$ & -0.17 & 0.416 \\
\hline Final visit & 18 & \begin{tabular}{l|l}
55 & $11.70 \pm 1.13$
\end{tabular} & 55 & $11.42 \pm 1.3$ & -0.28 & 0.314 \\
\hline
\end{tabular}

\begin{tabular}{|c|c|c|c|c|c|c|}
\hline \multirow{2}{*}{$\begin{array}{c}\text { Se. } \\
\text { ferritin }\end{array}$} & \multirow{2}{*}{$\begin{array}{c}\text { Wee } \\
k\end{array}$} & \multirow{2}{*}{$\frac{\text { Daily }}{\mathrm{g} / \mathrm{ml}}$} & \multirow{2}{*}{\multicolumn{2}{|c|}{$\begin{array}{l}\text { Weekly } \\
\mathrm{ng} / \mathrm{ml}\end{array}$}} & \multirow{2}{*}{$\begin{array}{l}\text { Difference } \\
\mathrm{ng} / \mathrm{ml}\end{array}$} & \multirow{2}{*}{$\begin{array}{c}\text { P- } \\
\text { Value }\end{array}$} \\
\hline & & & & & & \\
\hline eline & 0 & $55 \mid 18.41 \pm 21.97$ & & $9.96=$ & -8.45 & 0.02 \\
\hline hal visit & 18 & \begin{tabular}{l|l|l|}
55 & $21.24 \pm 26.25$
\end{tabular} & & $9.21 \pm 12.15$ & -12.03 & $0.10^{*}$ \\
\hline
\end{tabular}

\begin{tabular}{|l|l|l|l|l|l|l|l|}
\hline \multirow{2}{*}{ MCV } & \multirow{2}{*}{ Week } & \multicolumn{2}{|c|}{ Daily } & \multicolumn{2}{|c|}{ Weekly } & Difference FI & P-Value \\
\cline { 3 - 5 } & & N & FI & N & FI & & \\
\hline Baseline & 0 & 55 & $86.31 \pm 4.51$ & 55 & $87.63 \pm 5.21$ & 1.32 & 0.228 \\
\hline 1st visit & 4 & 28 & $85.12 \pm 7.85$ & 28 & $85.62 \pm 5.78$ & 0.41 & 0.871 \\
\hline 2nd Visit & 12 & 35 & $86.88 \pm 6.93$ & 45 & $84.19 \pm 5.21$ & -2.69 & 0.203 \\
\hline Final visit & 18 & 55 & $87.35 \pm 7.04$ & 55 & $86.36 \pm 7.56$ & -0.99 & 0.546 \\
\hline
\end{tabular}

The changes in hemoglobin and serum ferritin were related to the initial concentration of these variables (Table 4).

For those women who had a hemoglobin concentration $<11 \mathrm{gm} / \mathrm{dL}$ at the beginning, the rise in hemoglobin concentration was significantly greater at the end in the daily supplemented group as compared to the weekly group $(1.44 \pm 1.51 \mathrm{gm} / \mathrm{dl}$ vs. $0.12 \pm 1.05 \mathrm{gm} / \mathrm{dl}, \mathrm{p}=0.015$ ).

The mean serum ferritin level in the daily supplemented anemic subgroup increased from
$16.23 \pm 21.42 \mathrm{ng} / \mathrm{ml}$ to $21.14 \pm 26.66 \mathrm{ng} / \mathrm{ml}$. On the other hand, the mean serum ferritin level showed a decreasing trend from $9.00 \pm 7.33 \mathrm{ng} / \mathrm{ml}$ to $7.50 \pm 5.45 \mathrm{ng} / 1$ in the weekly anemic subgroup.

However, when the changes in the serum ferritin level which occurred in each group were compared, there was no significant difference $(p=0.415)$ between the two intervention groups.

For those women who started pregnancy with hemoglobin concentration $>11 \mathrm{gm} / \mathrm{dL}$, no statistically significant difference was noted between the two intervention groups with respect to change in hemoglobin $(p=0.871)$ and serum ferritin concentration $(p=0.741)$ at the end of the study period.

\section{Discussion}

Anemia is the most common nutritional deficiency disorder in pregnancy, worldwide. In India, approximately $62-88 \%$ of pregnant women are anemic [12]. Supplementation programs have been implemented since 1971 in India, and the dose of supplementation has been increased up to $100 \mathrm{mg}$ of elemental iron per day, yet the magnitude of the problem remains unchanged [12]. It is recognized that one of the major problems of daily supplementation schedule is lack of compliance because of the high incidence of gastrointestinal side effects.

Added to this are the recent concerns of molecular damage as a result of iron over-dosage [2]. Weekly iron supplements have been tried in some populations, with equal or sub-optimal benefits compared with those of daily supplementation $[8,10,13]$.

Since the effectiveness of large-scale supplementation programs has never been established, the International Nutritional Anaemia Consultative Group, the WHO and UNICEF are considering the option of intermittent iron supplementation as a therapeutic protocol [14].

Beaton and McCabe, in a meta-analysis of 21 published and unpublished studies regarding daily versus intermittent iron supplementation in various populations, found that there was a higher final hemoglobin concentration associated with the daily administration of iron [15]. From India, Gomber et al. studied daily versus weekly iron supplements in 80 pregnant women and concluded that weekly supplementation was as effective as daily [16]. 
Table 5: Prevalence of iron deficiency and anemia.

\begin{tabular}{|l|l|l|l|}
\hline \multicolumn{1}{|c|}{ Category } & \multicolumn{1}{|c|}{$\begin{array}{c}\text { Rajaratnam J et al } \\
\text { [18] }\end{array}$} & \multicolumn{1}{|c|}{$\begin{array}{c}\text { Present } \\
\text { study }\end{array}$} \\
\hline I. & No iron deficiency, no anemia & $25.2 \%$ & $27.3 \%$ \\
\hline II. & $\begin{array}{l}\text { Storage iron depletion, not } \\
\text { anaemic }\end{array}$ & $7.1 \%$ & $39.0 \%$ \\
\hline III & Iron deficiency anemia & $29.5 \%$ & $21.8 \%$ \\
\hline IV. & Anemia, but not iron deficient & $38.3 \%$ & $11.8 \%$ \\
\hline
\end{tabular}

However, only 56 women could be followed up until the time of final analysis and the women were predominantly non-anemic at the time of recruitment. The present study was therefore planned to address the feasibility of giving weekly

Supplements to pregnant Indian women. The study population consisted of a blend of urban and rural pregnant women attending the antenatal clinic of a referral center. A placebo group was not included because of ethical reasons. Because women with hemoglobin $<10 \mathrm{~g} / \mathrm{dL}$ were excluded from the study, it was not possible to calculate the exact prevalence of anemia. At the baseline, the overall prevalence of iron deficiency was $60.9 \%$ (67 out of 110 ) and the prevalence of IDA was $21.81 \%$ (24 out of 110 ). $11.81 \%$ of cases were anemic but not iron deficient. A study under a similar setting reported the prevalence of anemia in pregnancy was $30 \%$ in the urban area of Delhi [17]. Mean serum ferritin concentration in 110 women was $14.18 \pm 17.15$ $\mathrm{ng} / \mathrm{ml}$, this mean level is lower than those reported by other studies [19]. In the present study, weekly supplementation was as effective as daily supplementation in maintaining the hemoglobin level in pregnancy. However, because the majority of the pregnant women were non-anemic to start with, there was no further significant increase in the hemoglobin level in either group. In contrast, studies conducted in Indonesia, Malawi, and China have dealt with rural pregnant women who were primarily anemic. Hence a rise in the hemoglobin level was evident after iron therapy and a significant rise in hemoglobin level occurred in both treatment groups. At enrollment, the log serum ferritin level in the daily supplemented group was higher than that in the weekly supplemented group $(P=0.08)$. The difference in these values despite successful randomization can probably be explained by the fact that the sample size was small: five patients in the daily group had serum ferritin levels $\geq 90 \mathrm{ng} / \mathrm{mL}$, which resulted in an increase in the mean value. The final ferritin level was lower in the weekly
Group after adjusting for the initial difference and for other covariates. Although the final hemoglobin levels were not different between the two groups, daily supplementation proved to be superior to weekly supplementation in the anemic subgroup. Among the non-anemic women, more women in the weekly group $(10 / 30,33.3 \%)$ became anemic at the 34-week period of gestation compared with those in the daily group $(5 / 23,22 \%)$. Hemoglobin concentration increased to $>11 \mathrm{~g} / \mathrm{dL}$ by 34 weeks' gestation in anemic women receiving daily supplementation, but anemic women receiving weekly supplementation continued to be anemic after an average 17 weeks of iron supplementation. However, the majority of women who had become anemic at 34 weeks had hemoglobin concentrations between 10.5 and $10.9 \mathrm{~g} / \mathrm{dL}$, which according to the Center for Disease Control criteria [20] is approximately the fifth percentile of hemoglobin level at that period of gestation. This could be thus explained by physiological hemodilution. In a study by Milman et al., based on the hemoglobin concentrations seen in 206 pregnant women, it was concluded that a cut-off value of $10.5 \mathrm{~g} / \mathrm{dL}$ instead of $11 \mathrm{~g} / \mathrm{dL}$ should define pregnancy anemia in the second and third trimesters [21]. Low compliance with iron supplementation programs has been widely reported, with $60 \%$ of women verbally reporting compliance and only $32-36 \%$ of women complying with the prescribed schedule when checked using stool tests [22-24].

Table 6: Haemoglobin levels in various studies.

\begin{tabular}{|l|l|l|l|l|}
\hline \multicolumn{1}{|c|}{ Study } & \multicolumn{2}{|c|}{ Daily supplementation } & \multicolumn{2}{c|}{$\begin{array}{l}\text { Intermittent } \\
\text { Supplementation }\end{array}$} \\
\cline { 2 - 5 } & $\begin{array}{l}\text { Initial } \mathrm{Hb} \\
\mathrm{gm} / \mathrm{dl}\end{array}$ & $\begin{array}{l}\text { Final } \mathrm{Hb} \\
\mathrm{gm} / \mathrm{dl}\end{array}$ & $\begin{array}{l}\text { Initial } \mathrm{Hb} \\
\mathrm{gm} / \mathrm{dl}\end{array}$ & Final $\mathrm{Hb} \mathrm{gm} / \mathrm{dl}$ \\
\hline Ridwan et al [6] & $10.1 \pm 0.6$ & $10.9 \pm 0.7$ & $9.8 \pm 0.8$ & $10.6 \pm 0.7$ \\
\hline Young et al [8] & $10.5 \pm 1.4$ & $11.3 \pm 1.8$ & $10.4 \pm 1.5$ & $10.5 \pm 1.4$ \\
\hline $\begin{array}{l}\text { Mumtaz et al } \\
\text { [25] }\end{array}$ & $9.2 \pm 1.4$ & $11.3 \pm 1.8$ & $9.5 \pm 1.0$ & $10.0 \pm 1.2$ \\
\hline Present study & $11.3 \pm 1.0$ & $11.7 \pm 1.1$ & $11.6 \pm 0.9$ & $11.4 \pm 1.3$ \\
\hline
\end{tabular}

Table 7: Serum ferritin levels in the two intervention groups.

\begin{tabular}{|l|l|l|l|l|}
\hline \multicolumn{1}{|c|}{ Study } & \multicolumn{2}{c|}{ Daily suppl. } & \multicolumn{2}{c|}{ intermittent suppl. } \\
\hline & $\begin{array}{l}\text { Initial ferritin } \\
\mathrm{ng} / \mathrm{ml}\end{array}$ & $\begin{array}{l}\text { Final ferritin } \\
\mathrm{ng} / \mathrm{ml}\end{array}$ & $\begin{array}{l}\text { Initial ferritin } \\
\mathrm{ng} / \mathrm{ml}\end{array}$ & $\begin{array}{l}\text { Final ferritin } \\
\mathrm{ng} / \mathrm{ml}\end{array}$ \\
\hline $\begin{array}{l}\text { Ridwan et al } \\
{[6]}\end{array}$ & $28.0 \pm 19.2$ & $27.7 \pm 19.8$ & $23.2 \pm 20.5$ & $20.5 \pm 16.9$ \\
\hline $\begin{array}{l}\text { Mumtaz et al } \\
{[25]}\end{array}$ & $23.8 \pm 29.7$ & $41.6 \pm 34.9$ & $23.0 \pm 33.7$ & $27.6 \pm 31.5$ \\
\hline Present study & $18.41 \pm 21.97$ & $21.24 \pm 26.25$ & $9.96 \pm 8.74$ & $9.21 \pm 12.15$ \\
\hline
\end{tabular}


Table-8: Haemoglobin response in the anemic subgroup $(\mathrm{Hb}<11 \mathrm{gm} / \mathrm{dl})$.

\begin{tabular}{|c|c|c|c|c|c|c|}
\hline \multirow[t]{2}{*}{ Study } & \multicolumn{3}{|c|}{ Daily supplemented } & \multicolumn{3}{|c|}{ Intermittent Supplemented } \\
\hline & $\begin{array}{l}\text { Initial Hb } \\
\mathrm{gm} / \mathrm{dl}\end{array}$ & $\begin{array}{l}\text { Final Hb } \\
\mathrm{gm} / \mathrm{dl}\end{array}$ & $\begin{array}{l}\Delta \mathrm{gm} / \\
\mathrm{dl}\end{array}$ & $\begin{array}{l}\text { Initial Hb } \\
\mathrm{gm} / \mathrm{dl}\end{array}$ & $\begin{array}{l}\text { Final Hb } \\
\mathrm{gm} / \mathrm{dl}\end{array}$ & $\begin{array}{l}\Delta \mathrm{gm} / \\
\mathrm{dl}\end{array}$ \\
\hline $\begin{array}{l}\text { Mumtaz et } \\
\text { al [25] }\end{array}$ & $\begin{array}{l}9.26 \pm 1.41( \\
n=100)\end{array}$ & $\begin{array}{l}11.36 \pm 1.83 \\
(n=55)\end{array}$ & 2.10 & $\begin{array}{l}9.58 \pm 1.06( \\
n=91)\end{array}$ & $\begin{array}{l}10.09 \pm 1.23 \\
(n=50)\end{array}$ & 0.51 \\
\hline $\begin{array}{l}\text { Ridwan et } \\
\text { al [6] }\end{array}$ & $\begin{array}{l}10.1 \pm 0.6(n \\
=45)\end{array}$ & $\begin{array}{l}10.9 \pm 0.7(n \\
=45)\end{array}$ & $\begin{array}{l}0.8 \pm 0 \\
.8\end{array}$ & $\begin{array}{l}9.8 \pm 0.8(n= \\
54)\end{array}$ & $\begin{array}{l}10.6 \pm 0.7(n \\
=54)\end{array}$ & $\begin{array}{l}0.8 \pm 0 \\
7\end{array}$ \\
\hline $\begin{array}{l}\text { Young et al } \\
{[8]}\end{array}$ & $(n=70)$ & & $\begin{array}{l}0.63 \pm \\
1.26\end{array} \mid$ & $(n=66)$ & & $\begin{array}{l}0.59 \pm \\
1.18\end{array}$ \\
\hline $\begin{array}{l}\text { Present } \\
\text { study }\end{array}$ & $\begin{array}{l}10.30 \pm 0.31 \\
(n=23)\end{array}$ & $11.74 \pm 1.34$ & $\begin{array}{l}1.44 \pm \\
1.51\end{array}$ & $\begin{array}{l}10.48 \pm 0.26 \\
(n=14)\end{array}$ & $10.60 \pm 0.97$ & $\begin{array}{l}0.12 \pm \\
1.05\end{array}$ \\
\hline
\end{tabular}

Table-9: Haematological indices in pregnancy.

\begin{tabular}{|c|c|c|c|c|c|c|c|}
\hline \multirow[t]{2}{*}{ Analysis } & \multirow[t]{2}{*}{ Therapy } & \multicolumn{2}{|c|}{$<15$ weeks } & \multicolumn{2}{|c|}{ 26-30 weeks } & \multicolumn{2}{|c|}{ 33-34 weeks } \\
\hline & & $\begin{array}{l}\text { Taylor et } \\
\text { al }\end{array}$ & $\begin{array}{l}\text { Presen } \\
t\end{array}$ & $\begin{array}{l}\text { Taylor et } \\
\text { al }\end{array}$ & $\begin{array}{l}\text { Presen } \\
t\end{array}$ & $\begin{array}{l}\text { Taylor et } \\
\text { al }\end{array}$ & $\begin{array}{l}\text { Presen } \\
t\end{array}$ \\
\hline \multirow[t]{3}{*}{$\mathrm{Hb}$ gm/dl } & Daily iron & 12.42 & 11.32 & 11.42 & 11.38 & 11.80 & 11.70 \\
\hline & No iron & 12.23 & & 11.22 & & 11.04 & \\
\hline & $\begin{array}{l}\text { Weekly } \\
\text { iron }\end{array}$ & & 11.63 & & 11.21 & & 34.42 \\
\hline \multirow[t]{3}{*}{ HCT \% } & Daily iron & 35.98 & 34.06 & 33.27 & 29.04 & 34.42 & 34.38 \\
\hline & No iron & 35.25 & & 32.74 & & 32.41 & \\
\hline & $\begin{array}{l}\text { Weekly } \\
\text { iron }\end{array}$ & & 34.94 & & 33.70 & & 34.73 \\
\hline \multirow[t]{3}{*}{$\mathrm{MCV} \mathrm{fl}$} & Daily iron & 83.62 & 86.31 & 87.63 & 86.88 & $\begin{array}{l}87.79 / \mathrm{td} \\
>\end{array}$ & 87.35 \\
\hline & No iron & 84.63 & & 88.03 & & 86.01 & \\
\hline & $\begin{array}{l}\text { Weekly } \\
\text { iron }\end{array}$ & & 87.63 & & 84.19 & & 86.36 \\
\hline \multirow[t]{3}{*}{$\mathrm{MCH}$ pg } & Daily iron & 28.87 & 29.15 & 30.20 & 29.45 & 29.22 & 29.70 \\
\hline & No iron & 29.35 & & 30.32 & & 29.43 & \\
\hline & $\begin{array}{l}\text { Weekly } \\
\text { iron }\end{array}$ & & 29.00 & & 29.17 & & 28.43 \\
\hline \multirow{3}{*}{$\begin{array}{l}\mathrm{MCHC} \\
\mathrm{gm} / \mathrm{dl}\end{array}$} & Daily iron & 34.27 & 33.43 & 34.12 & 35.33 & 34.13 & 3394 \\
\hline & No iron & 34.49 & & 34.19 & & 33.92 & \\
\hline & $\begin{array}{l}\text { Weekly } \\
\text { iron }\end{array}$ & & 32.51 & & 32.64 & & 32.92 \\
\hline
\end{tabular}

Table-10: Comparison of compliance between the daily and weekly supplemented group.

\begin{tabular}{|l|l|l|l|l|}
\hline \multicolumn{1}{|c|}{ Studies } & \multicolumn{1}{|c|}{ Compliance checked } & Daily & $\begin{array}{l}\text { Weekl } \\
\text { y }\end{array}$ & P-value \\
\hline $\begin{array}{l}\text { Ridwan et al } \\
\text { [6] }\end{array}$ & Stool test & $\begin{array}{l}54.3 \\
\%\end{array}$ & $62.2 \%$ & NS \\
\hline Young et al [8] & Self-reporting and pill counting & $\begin{array}{l}59.8 \\
\%\end{array}$ & $76.0 \%$ & $0.011^{*}$ \\
\cline { 2 - 5 } & Stool test & $\begin{array}{l}61.8 \\
\%\end{array}$ & $59.6 \%$ & NS \\
\hline Present study & $\begin{array}{l}\text { Self-reporting and pill } \\
\text { counting/td> }\end{array}$ & $40 \%$ & $85.5 \%$ & $<0.001 *$ \\
\hline
\end{tabular}

Table-11: Relation between side effects and compliance.

\begin{tabular}{|l|l|l|l|l|l|}
\hline \multirow{2}{*}{ Studies } & \multicolumn{3}{c|}{ Side effects (SE) } & \multicolumn{2}{c|}{ Compliance } \\
\cline { 2 - 6 } & Daily & Weekly & P-value & SE+ve & SE-ve \\
\hline Young et al [8] & $17 \%$ & $6 \%$ & $0.01 *$ & $60 \%$ & $68 \%$ \\
\hline Ridwan et al [6] & $16.2 \%$ & $18.3 \%$ & NS & $20.8 \%$ & $63.5 \%$ \\
\hline Present study & $49 \%$ & $10.9 \%$ & $<0.01 *$ & $16.6 \%$ & $66 \%$ \\
\hline
\end{tabular}

*Significant

Table-12: Relation between maternal hemoglobin, birth weight, and period of gestation.

\begin{tabular}{|c|c|c|c|}
\hline Studies & $\begin{array}{l}\text { Maternal } \\
\text { Hb/serum } \\
\text { ferritin }\end{array}$ & $\begin{array}{c}\text { Birth of wt. (gm) } \\
\text { (Mean } \pm \text { SD) }\end{array}$ & $\begin{array}{c}\text { POG at delivery } \\
\text { (weeks) (Mean } \pm \text { SD) }\end{array}$ \\
\hline \multirow[t]{2}{*}{$\begin{array}{l}\text { Agarwal et } \\
\text { al [26] }\end{array}$} & $\mid \begin{array}{l}\mathrm{Hb} 8.6-10.9 \\
\mathrm{gm} / \mathrm{dL}(\mathrm{n}=17)\end{array}$ & $2760.2 \pm 410.50$ & $39.4 \pm 1.64$ \\
\hline & $\begin{array}{l}\mathrm{Hb}>11 \mathrm{gm} / \mathrm{dL} \\
(\mathrm{n}=21)\end{array}$ & $2759.5 \pm 352.35$ & $37.7 \pm 5.49$ \\
\hline \multirow[t]{2}{*}{$\begin{array}{l}\text { Bhargava } \\
\text { et al [27] }\end{array}$} & $\begin{array}{l}\text { Se Fe }>10 \mathrm{ng} / \mathrm{ml} \\
(\mathrm{n}=45)\end{array}$ & $2518.75 \pm 508.00$ & $37.55 \pm 2.05$ \\
\hline & $\begin{array}{l}\text { Se Fe }>10 \mathrm{ng} / \mathrm{ml} \\
(\mathrm{n}=263)\end{array}$ & $2552.33 \pm 566.06$ & $37.59 \pm 1.98$ \\
\hline \multirow[t]{2}{*}{$\begin{array}{l}\text { Present } \\
\text { study }\end{array}$} & $\begin{array}{l}\mathrm{Hb}<11 \mathrm{gm} / \mathrm{dl} \\
(\mathrm{n}=37)\end{array}$ & $<2.5 \mathrm{~kg}(13.5 \%)$ & $38.66 \pm 1.17$ \\
\hline & $\begin{array}{l}\mathrm{Hb}>11 \mathrm{gm} / \mathrm{dl} \\
(\mathrm{n}=73)\end{array}$ & $<2.5 \mathrm{~kg}(9.5 \%)$ & $38.33 \pm 1.42$ \\
\hline
\end{tabular}

In the present study, $67.7 \%$ of women in the daily group were non-compliant and gastrointestinal sideeffects were responsible for this in $75 \%$ of cases. In the weekly group, only $15 \%$ did not comply with the prescribed schedule, the major reason being forgetting to take iron pills after an interval of a week. In the present study, though the anemic subgroup supplemented weekly did not show any rise in the final hemoglobin concentration, the effect was not translated into adverse pregnancy outcomes like low birth weight or preterm deliveries. The results are in accordance with earlier studies, in which mild anemia in pregnancy was not related to an increased incidence of preterm or low birth weight babies, although babies born to severely anemic mothers did have lower birth weights and shorter gestation [17].

\section{Conclusion}

To conclude, overall, the intermittent iron supplementation did not differ from the daily supplementation in terms of hematological response. Also the subjects had low-grade anemia initially and actually a very small dosage of iron was 
Needed for them to reach their optimal hemoglobin concentrations. These may be the reasons that no significant difference was observed between the two treatment regimens. The same holds true for the present study where all women had hemoglobin level $\geq 10 \mathrm{gm} / \mathrm{dl}$ and were supplemented for 17 weeks on an average. The issue of whether weekly iron supplementation leads to folic acid deficiency as well because the daily recommended allowance of $400 \mu \mathrm{g} /$ day is not fulfilled in a weekly schedule was not investigated.

There was no evidence of macrocytosis in women who remained anemic at the end of supplementation. Serum folic acid levels were not measured. Iron supplementation works in a complex multidimensional context that includes sociocultural, economic, and political facets. It is important to look at the effectiveness of otherwise efficacious regimens in field conditions and not take decisions based on perceived efficiencies alone. Further studies, especially in developing countries, on a large scale are required to consolidate the basis of implementing weekly iron supplementation programs.

\section{What does the study add to the existing knowledge?}

In non - anemic pregnant women, there is no demonstrable benefit of daily supplementation in terms of hemoglobin rise, improved ferritin levels, or perinatal outcome. On the other hand, there are significantly fewer side effects and patients are happier and more compliant with the weekly regimen. Intermittent iron dosing as a prophylactic supplementation can adequately meet the increased demands of pregnancy even if they are iron deficient.

However in anemic women, even with mild anemia, daily supplementation appears to be superior to weekly supplementation and the present study shows less than optimal benefits in terms of raising hemoglobin in the weekly supplemented group, though small sample size precludes statistical relevance.

Meanwhile it appears that though an effective alternative for prophylactic supplementation, for therapeutic supplementation in mild and moderately anemic women, larger field base trials are required to substantiate the efficacy of intermittent iron supplementation as a public health strategy especially in a developing country like India.

\section{Author's contribution}

Dr. Shrikrishna Kumar Agrawal: Study design, concept

Dr. Monika Jindal: Statistical analysis, manuscript preparation

\section{Reference}

01. Vijayaraghavan K, Brahmam GN, Nair KM, Akbar D, Rao NP. Evaluation of national nutritional anemia prophylaxis programme. Indian $\mathrm{J}$ Pediatr. 1990;57(2)183-190.

doi: [Article:https://doi.org/10.1007/bf02722084] [Crossref]

02. Solomons NW, Pineda O, Viteri FE, Sandstead $\mathrm{HH}$. Studies on the bioavailability of zinc in humans- mechanism of the intestinal interaction of non-heme $\mathrm{Fe}$ and Zinc. J Nutr. 1983;113(2)927-935.

doi: [Article:https://doi.org/10.1093/jn/113.2.337] [Crossref]

03. O'?Neil-Cutting MA, Crosby WH. Blocking of iron absorption by a preliminary oral dose of iron. Arch Intern Med. 1987;147(3)489-491. [Crossref]

04. Viteri FE. Weekly compared with daily iron supplementation. Am J Clin Nutr. 1996;63(4)610-611.

doi: [Article:https://doi.org/10.1093/ajcn/63.4.610] [Crossref]

05. Viteri FE. A new concept in the control of iron deficiency- community based preventive supplementation of at risk groups by the weekly intermittent iron supplements. Biomed Environ Sci. $1998 ; 11(1) 46-60$.

[Crossref]

06. Ridwan E, Schultink W, Dillon D, Gross R. Effects of Weekly iron supplementation on pregnant Indonesian women are similar to those of daily supplementation. Am J Clin Nutr. 1996;63(6)884-890.

doi:[Article:https://doi.org/10.1093/ajcn/63.6.884] [Crossref]

07. Liu XN, Zhang JL, Yen $\mathrm{HL}$, Viteri FE. Haemoglobin and serum ferritin levels in pregnant Chinese women in response to weekly iron supplements. [Abstract] In;7th Asian Congress of Nutrition. Beijing, 1995.

[Crossref] 
08. Young MW, Lupafya E, Kapendra E, Bobrow E. The effectiveness of weekly iron supplementation in pregnant women of rural northern Malawi. Tropical Doctor. 2000;30(2)8488.

doi:

[Article:https://doi.org/10.1177/0049475500030002 10][Crossref]

09. Rajaratnam J, Abel R, Ganesan C, Jayaseelan SA. Maternal anaemia- A persistent problem in rural Tamil Nadu. Natl Med J Ind. $2000 ; 13(5) 242-245$.

[Crossref]

10. World Health Organization. The prevalence of anaemia in women- a tabulation of available information. 2nd ed; WHO. Geneva 1992 (WHO/MCH/MSM 92.2).

Available

at[Article:https://apps.who.int/iris/handle/10665/589 94][Crossref]

11. Svanberg B. Iron absorption in early pregnancy - a study of the absorption of non-haem iron and ferrous iron in early pregnancy. Actabstet Gynecol Scand. 1975;48;69-85.

doi: [Article:https://doi.org/10.3109/000163475 09156331][Crossref]

12. Taylor DJ, Ling T. Haematological changes during normal pregnancy- Iron induced macrocytes: $\mathrm{Br} \mathrm{J}$ Obstet Gynaecol 1976;83(10)760-767.

doi: https://doi.org/10.1111/j.1471-0528.1976.tb

00740.x [Crossref]

13. Taylor DJ, Lind T. Red cell mass during and after normal pregnancy. $\mathrm{Br} J$ Obstet Gynaecol. 1979;86(5)364-370.

doi: [Article:https://doi.org/10.1111/j.1471-0528.

1979.tb10611.x][Crossref]

14. Stoltzfus RJ, Dreyfuss ML. Guidelines for the use of iron supplements to prevent and treat iron deficiency anemia. Washington, DC; Ilsi Press. 1998.

Available at:[Article][Crossref]

15. Beaton GH, McCabe GP. Micronutrient InitiativeEfficacy of intermittent iron supplementation in the control of iron deficiency anaemia in developing countries- an analysis of experience; final report to the Micronutrient Initiative. Micronutrient Initiative, Ottawa, ON. CA; 1999. Available at [Article][Crossref]
16. Agarwal KN, Gomber S, Bisht H, Som M. Anemia prophylaxis in adolescent school girls by weekly or daily iron-folate supplementation. Indian Pediatr. 2003;40(4)296-302.

[Crossref]

17. Mukhopadhyay A, Bhatla N, Kriplani A, Pandey RM, Saxena R. Daily versus intermittent iron supplementation in pregnant womenhematological and pregnancy outcome. J Obstet Gynaecol Res. 2004;30(6)409-417. doi:[Article:https://doi.org/10.1111/j.1447-0756. 2004.00223.x][Crossref]

18. Rajaratnam J, Abel R, Ganesan C, Jayaseelan SA. Maternal anaemia- a persistent problem in rural Tamil Nadu. Nat Med J India. 2000 ;13(5)242-245.

[Crossref]

19. Beard JL. Weekly iron intervention- the case for intermittent iron supplementation. Am J Clin Nutr. 1998;68(2)-209-121.

doi: [Article:https://doi.org/10.1093/ajcn/68.2.209] [Crossref]

20. Younes M, Eberhrdt I, Lemoine R. Effect of iron overload on spontaneous and xenobiotic induced lipid peroxidation in vivo. J Appl Toxicol. 1989;9(2)103-108.

doi:

[Article:https://doi.org/10.1002/jat.2550090206]

[Crossref]

21. Knutson MD, Walter PB, Ames BN, Viteri FE. Both iron deficiency and daily iron supplements lipid peroxidation in rats. J Nutr. 2000;130(3)621-628.

doi: [Article:https://doi.org/10.1093/jn/130.3.621][ Crossref]

22. Viteri FE, Xunian L, Tolomei K, Martin A. True absorption and retention of supplementation iron is more efficient when iron is administered every three days rather than daily to ironnormal and iron deficient rats. J Nutr. 1995; 125(1)82-91.

doi: [Article:https://doi.org/10.1093/jn/125.1.82] [Crossref]

23. Schultink W, Gross R, Gliwitzki M, Karyadi D, Matulessi $P$. effect of daily vs twice weekly iron supplementation in Indonesian preschool children with low iron status. Am J Clin Nutr. 1995;61(1)111-115.

doi: [Article:https://doi.org/10.1093/ajcn/61.1.111] [Crossref] 
24. Beard JL. Effectiveness and strategies of iron supplementation during pregnancy. Am J Clin Nutr. 2000;71(5)1288S-1294S.

doi:

[Article:https://doi.org/10.1093/ajcn/71.5.1288s] [Crossref]

25. Mumtaz Z, Shahab S, Butt N, Ral MA, DeMuynck A. Daily iron supplementation is more effective than twice weekly iron supplementation in pregnant women in Pakistan in a randomized double-blind clinical trial. J Nutr. 2000;130(11)2697-2702.

doi: [Article:https://doi.org/10.1093/jn/130.11.2697] [Crossref]
26. Agarwal A, Rai S, Prasad R. Impact of the Integrated Child Development Services (ICDS) on Maternal Nutrition and Birth Weight in Rural Varanasi KN Agarwal, DK Agarwal. Indian Pediatr. 2000;37(12)1321-1327.

[Crossref]

27. Bhargava M, Iyer PU, Kumar R. Relationship of maternal serum ferritin with foetal serum ferritin, birth weight and gestation. J Trop Pediatr. $1991 ; 37(4) 149-152$.

doi:

[Article:https://doi.org/10.1093/tropej/37.4.149]

[Crossref] 